\title{
ENTREPRENEURSHIP COMPETENCE OF THE PRINCIPAL IN IMPROVING SCHOOL INDEPENDENCE IN SD MUHAMMADIYAH KLECO 2 KOTAGEDE YOGYAKARTA
}

\author{
Sandi Syapriyuda ${ }^{\otimes} 1$ Achadi Budi Santosa ${ }^{2}$ \\ Education Management Department. \\ Ahmad Dahlan University Yogyakarta. \\ Email : sandiyuda2877@gmail.com
}

\begin{abstract}
The purpose of this study is to know : (1). entrepreneurship competencies of the principal of SD Muhammadiyah Kleco 2 Kotagede Yogyakarta. (2). programs that carried out by school principals in developing school potential, and (3) the competence of principals increases school independence.

This research uses a qualitative approach. Data collection is done by observation, in-depth interviews, and documentation studies. Conclusions are drawn in a variety of extrapolations based on the reliability of research findings. While the validity of the data is carried out in terms of credibility, transferability, and confirmation.

The results of the study are as follows (1). The principal of the Muhammadiyah Kleco 2 Elementary School has good entrepreneurial competence, as evidenced by (a). innovations made. (b). work hard to achieve school success. (c). strong motivation for success. (d). always looking for the best solution in facing obstacles faced by schools. (e). The principal has an entrepreneurial instinct in managing school activities as a source of learning for students (2). Able to plan and run school programs and develop school potential. (3). Able to increase school independence.
\end{abstract}

Keywords: Entrepreneurship Competence, School Independence, School Principal Competence.

Introduction The competency that must be possessed by the Principal based on the Minister of National Education Regulation No. 13/2007 concerning the Principal Standards consists of 5 competencies: Managerial Competence, Supervision Competency, Personality Competency, Social Competence and Competency Entrepreneurship. (Kemendiknas, 2007). One of the principals' competencies which is quite central is entrepreneurial competencies. As one way to able realize the ability in this entrepreneurship, the principal must be able to demonstrate the ability to establish partnerships with parties outside of school, and be able to make the school independent with entrepreneurial efforts.

Principals who have entrepreneurial competencies can be seen from the abilities that include: (1). Creating innovations that are useful for the development of schools. (2). Work hard to achieve school success as an effective learning organization. (3). Have a strong motivation to succeed in carrying out their main duties and functions as school leader. (4). Never give up and always look for the best solution in dealing with obstacles faced by schools. (5). Having an 
entrepreneurial instinct in managing school / madrasah production / service activities as a source of student learning. (Kemendiknas, 2007)

Faturrahman in (Fathurrahman Fathurrahman, 2018) examined the entrepreneurial leadership of school principals in achieving high school achievement, a case study in SMP Negeri 1 Lamongan. Through interviews, observations and documentation, research shows that the successful application of the principals' entrepreneurial leadership, SMP Negeri 1 Lamongan became an advanced and outstanding school. Likewise, (Sariyasni1, 2018) which examines the role of principals' entrepreneurial competence in improving school quality in Makarti Jaya High School, 2018/2019 school year, seen from 1) context, 2) inputs, processes, and 4) products of roles Principal's entrepreneurial competence, through interviews, and analyzed descriptively The results of the study are good context, input, process and products and are able to improve school quality. Furthermore (Zaidatol Akmaliah Lope Pihie, 2018) in the Relationship between Entrepreneurial Leadership and School Effectiveness among Secondary Schools examines the application of entrepreneurial leadership in the educational context. through survey methods and analyzed using descriptive and inferential statistical analysis (Pearson correlation and multiple regression). shows that there is a significant and strong relationship between entrepreneurial leadership practices and school effectiveness

There are no studies on the 3 studies above that have examined the entrepreneurial competence of principals related to school independence, whereas school independence is very important because the Independent Category Schools (SKM) schools are able to optimize the achievement of educational goals (Wahab, 2012). This school is mostly done at junior high school or high school / high school so it is interesting to examine this at the elementary level.

Entrepreneurship competency research related to school independence at the elementary level will add to the scientific nature and insight for school principals and education practitioners in applying the entrepreneurial competency of principals in their respective educational units. The theoretical contribution of this research is expected to be able to enrich alternative theories about the competency of principals' entrepreneurial competencies.

\section{Literature Review}

(Abbas S. \&., 2004) also explained that entrepreneurial competence in educational institutions contained two meanings and applications, namely: a) efforts to apply entrepreneurial values in managing educational institutions; b) utilize the potential possessed / can be pursued by an educational institution into economic activities so as to generate profits that can 
be used to advance the educational institution concerned.

\begin{tabular}{|l|l|l|l|l|l|l|}
\hline 4 & Librarian & 1 & & 1 & 1 & \\
\hline 5 & Administration & 1 & 1 & & 1 & \\
\hline 6 & Employee & 2 & 1 & 1 & 2 & \\
\hline
\end{tabular}

According to (Mulyasa E. , 2005) in realizing an effective, productive, independent and acute school, the principal is required to have at least 10 (ten) keys to success in his leadership. The ten keys to successful leadership include (1). Having a complete vision. (2). Responsibility. (3). Exemplary. (4). Provide the best service. (5). Developing teachers and staff. (6). Fostering a sense of unity and unity (7). Management that prioritizes practice. (8). Adjust leadership style (9). Focus on students. (10). Make use of power and expertise to empower schools.

\section{Method and Design Research}

This research uses descriptive qualitative research methods. Because this research explores the competency of school principals in increasing school independence. In additional this research is also inductive and the results emphasize more meaning. The data used in this study were in the form of data from interviews with key informants, field observation data, and documentation studies in the field relating to the research discussion. In the selection of informants, using a purposive sampling method. The following are key informants in this research

Table 1 Key Informants

\begin{tabular}{|l|l|c|c|c|c|c|}
\hline \multirow{2}{*}{ NO } & \multirow{2}{*}{ Position } & \multirow{2}{*}{$\begin{array}{c}\text { Am } \\
\text { ount }\end{array}$} & \multicolumn{2}{|c|}{ Sex } & \multicolumn{2}{c|}{$\begin{array}{c}\text { Educati } \\
\text { on }\end{array}$} \\
\cline { 4 - 8 } & & & $M$ & P & S1 & S2 \\
\hline 1 & Headmaster & 1 & 1 & & & 1 \\
\hline 2 & Teacher & 3 & & 3 & 2 & 1 \\
\hline 3 & BUMS Manager & 1 & & 1 & 1 & \\
\hline
\end{tabular}

The data validity checking technique in this study is using triangulation. Triangulation is a technique for checking the validity of data by using something other than the data for checking purposes or as a comparison of the data. In this study, researchers used two types of triangulation namely source triangulation and technique triangulation

Source triangulation is to test the credibility of the data carried out by checking the data that has been obtained through several sources. Triangulation of this source is used by researchers to check data obtained from principals, teachers and employees of SD Muhammadiyah Kleco Kotagede 2 Yogyakarta,

While technical triangulation is to test the credibility of the data carried out by checking the data to the same source with different techniques. Triangulation of this technique is used by researchers after getting interview results and checked with the results of observation and documentation. The three techniques will produce a conclusion related to the principal's competence in increasing school independence.

\section{RESULTS}

\section{Principal Entrepreneurship Competency.}


The principal of the Muhammadiyah Kleco 2 Elementary School has good entrepreneurial competence. The principal of the Muhammadiyah Kleco 2 Elementary School was able to implement innovative programs to improve school effectiveness in the form of reforms in several fields, namely: 1). Learning Innovation. 2). SchoolOwned Business Entity (BUMS). 3). School canteen. 4). Admission of New Students (PPDB). 5). Extracurricular activities. 6). Construction of School Mini Market. 7). Child Psychology Services. This innovation has made the school more attractive to the community, as seen in the increasing number of new student admission each year.

Tablel 2

\section{New Student Admission Data}

\section{New Student Admission Data}

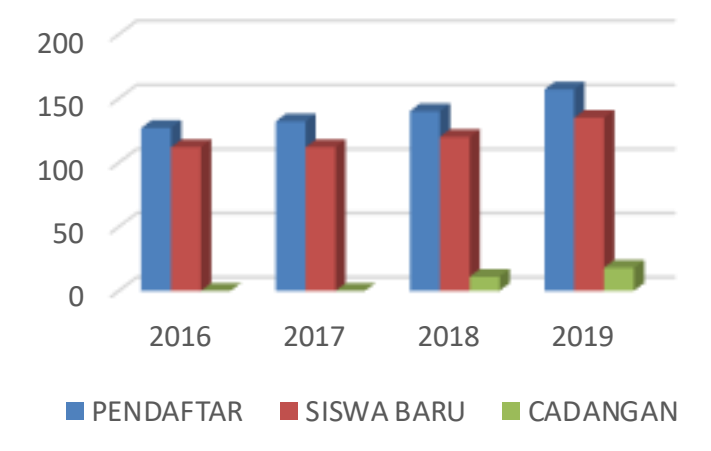

The Principal of Muhammadiyah Kleco 2 Elementary School consistently develops and implements effective learning programs such as completing learning support facilities such as LCDs in each class and Interactive CDs. Improving the quality of teachers by holding training, seminars and workshops development of learning support programs is also consistently carried out such as computer laboratories, libraries and also the existence of psychological services for students. Effective learning has an impact on student achievement:

Table 3

National Exam Scores

\begin{tabular}{|l|c|c|c|}
\hline $\begin{array}{l}\text { Descripti } \\
\text { on }\end{array}$ & $\begin{array}{c}\text { TA } \\
\mathbf{2 0 1 6 / 2 0} \\
\mathbf{1 7}\end{array}$ & $\begin{array}{c}\text { TA } \\
\mathbf{2 0 1 7 / 2 0} \\
\mathbf{1 8}\end{array}$ & $\begin{array}{c}\text { TA } \\
\mathbf{2 0 1 8 / 2 0} \\
\mathbf{1 9}\end{array}$ \\
\hline $\begin{array}{l}\text { Avarage } \\
\text { Score }\end{array}$ & 23,00 & 22,22 & 23,20 \\
\hline $\begin{array}{l}\text { Hightest } \\
\text { Score }\end{array}$ & 27,80 & 27,00 & 27.90 \\
\hline Ranking & 27 & 22 & 19 \\
\hline
\end{tabular}

From interviews and direct observation of researchers, it appears that the Principal of Muhammadiyah Kleco 2 Elementary School has a high willingness to achieve success in carrying out the main tasks and functions as school leaders. This can be proven from the results of research such as the statement of the principal who said that he was not satisfied with the results that have been achieved at this time. Muhammadiyah Kleco Elementary School is a developing school, so it is realized that there are still many shortcomings and this is a motivation for principals to continue to develop the potential that exists in schools for the realization of school progress and independence. As example is the effort to develop BUMS, school canteen and also the school library. both the school canteen and the school library have succeeded in making a proud achievement. Learning development programs and extracurricular activities are also evidence of the 
principal's efforts to achieve success, share championships and achievements that have been achieved by students both academically and academically, and this is evidence that the principal has a strong will to succeed.

The principal of the Muhammadiyah Kleco 2 Elementary School has a high willingness to achieve success in carrying out the main tasks and functions as school leaders. The principal continues to develop the potential that exists in the school in order to realize the progress and independence of the school. As example is the effort to develop BUMS, school canteen and also school library. both the school canteen and the school library have succeeded in making a proud achievement. The following is a summary

Table 4

BUMS financial report

\begin{tabular}{|c|c|c|c|}
\hline No & $\begin{array}{c}\text { Descript } \\
\text { ion }\end{array}$ & Amount & Information \\
\hline 1 & $\begin{array}{l}\text { SHU for } \\
\text { Teacher } \\
\text { s and } \\
\text { Employ } \\
\text { ees }\end{array}$ & Rp. 23.386 .866 & $\begin{array}{l}\text { Distributed } \\
\text { at the end of } \\
\text { the year } \\
\text { taken from } \\
54 \% \text { of BUMS } \\
\text { profits }\end{array}$ \\
\hline 2. & $\begin{array}{l}\text { Teacher } \\
\text { and } \\
\text { employ } \\
\text { ee } \\
\text { lunch }\end{array}$ & Rp. 24.400 .000 & $\begin{array}{l}\text { For one } \\
\text { second } \\
\text { twice }\end{array}$ \\
\hline 3. & $\begin{array}{l}\text { Mini } \\
\text { market } \\
\text { develop } \\
\text { ment }\end{array}$ & Rp. 35.000 .000 & \\
\hline 4. & $\begin{array}{l}\text { School } \\
\text { car } \\
\text { installm } \\
\text { ents }\end{array}$ & Rp. 16.000 .000 & $\begin{array}{l}\text { Paid per } \\
\text { year is taken } \\
\text { from } 40 \% \text { of } \\
\text { the } \\
\text { cafeteria } \\
\text { profit. }\end{array}$ \\
\hline
\end{tabular}

In the context of the realization of the principals' entrepreneurial competence, a school principal plans and implements work programs that aim to develop the potential of the school in order to make schools of higher quality and become independent schools. Work programs undertaken include: Human Resource Development and improvement of Teacher Welfare, these can be seen in the following table

Table 5

Human Resource Development

\begin{tabular}{|c|l|c|c|}
\hline No & \multicolumn{1}{|c|}{ Name } & Education & Status \\
\hline 1 & Amirudin & S2 & Graduate \\
\hline 2 & $\begin{array}{l}\text { Sri } \\
\text { Wahyuningsih }\end{array}$ & S2 & Graduate \\
\hline 3 & $\begin{array}{l}\text { Gesang } \\
\text { Setyo Aji }\end{array}$ & S2 & Studying \\
\hline 4 & $\begin{array}{l}\text { Ulva Dian } \\
\text { Citra Resmi }\end{array}$ & S2 & Studying \\
\hline 5 & Sumirah & S1 PGSD & Graduate \\
\hline 6 & $\begin{array}{l}\text { Siti Nasiah } \\
\text { Alusiah }\end{array}$ & S1 & Graduate \\
\hline 7 & $\begin{array}{l}\text { Wiwik } \\
\text { Sulistyaningsih }\end{array}$ & S1 & Graduate \\
\hline 8 & Pradeka Tiwi & S1 & Graduate \\
\hline
\end{tabular}

2. Entrepreneur Competence in Increasing School Independence

The principal of the SD Muhammadiyah Kleco 2 school has created innovative programs by optimizing the potential that exists in the school. Human resource development, improvement of supporting facilities for teaching and learning, quality extracurricular programs and improving the quality of learning in the classroom are efforts to improve the quality of graduates who are expected to have skills that are 
useful for their future. These efforts are the main attraction of the school so that it impacts on the independence of the school, the school is able to manage and optimize the existing potential so that the financial needs of the school can be met with the management of income that can be

One finding that proves school independence is a variety of extracurricular programs that are well managed. Schools can carry out activities in the school does not have to depend on service and requirements means that these activities are indeed undertaken by optimizing all the potential that exists in the school. for an example carrying out training workshops or self-training activities, extracurricular activities are also carried out by carrying out collaboration with partners who are experts in their fields. For example, the English Club cooperates with the language institutions, even for the time being cooperating with the PBI UAD Study Program. And funding is borne from the BOS costs of students free of charge. For some extracurricular activities it is paid like Violin, Angklung, Science club, but all can run well, and can be a place to develop students' talents. This extracurricular program can be described as follows:

Table 6

Extracurricular Activities

\begin{tabular}{|l|l|l|l|}
\hline NO & Activities & Participant & information \\
\hline 1 & Tapak Suci & Kls 4-5 & Mandatory \\
\hline 2 & HW & Kelas 4-5 & Mandatory \\
\hline 3 & Renang & Kelas 3 & Mandatory \\
\hline 4 & English Club & Kls 4,5,6 & Mandatory \\
\hline 5 & Olympiade & Kelas 4,5 & Selection \\
\hline
\end{tabular}

\begin{tabular}{|l|l|l|l|}
\hline 6 & Angklung & Kelas 1-5 & Selection \\
\hline 7 & Biola & Kelas 1-5 & Selection \\
\hline 8 & Seni Tari & Kelas 1-5 & Selection \\
\hline 9 & Pantomim & Kelas 4-5 & Selection \\
\hline 10 & Jurnalistik & Keas 4,5 & Selection \\
\hline 11 & Sains Club & Kelas 4,5 & Selection \\
\hline 12 & Futsal & Kls 3,4,5 & Selection \\
\hline 13 & Melukis & Kelas 4,5 & Selection \\
\hline 14 & Adzan & Kelas 3,4 5 & Selection \\
\hline 15 & Qiroah & Kelas 4,5 & Selection \\
\hline
\end{tabular}

For the development of the school in terms of the independence of this school the principal has made a concept including, the existence of a healthy canteen. The initial and main purpose is to serve healthy food for children. But in its development then this healthy canteen became one of the icons of the SD Muhammadiyah Kleco and succeeded in becoming Champion 2 of the healthy canteen at the national level. From this healthy canteen, profits can also be made that can be used as additional school income. and we also allocate additional input as one of the additional SHU friends. Even from this healthy canteen we can have a fleet of school cars.

The principal's courage in taking risks is also evident in several programs that have been carried out by the principal. As stated in the interview that the principal must not only innovate but must also dare to take risks when constrained by funding for example in the development of the school canteen there are also challenges and risks that are not small, but with high optimism and good organization these business units can currently develop well 
According to the explanation above, SD Muhamamdiyah Kleco 2 is already at the level of an independent school, because this school already has the initiative to meet all its needs and be able to solve its problems by optimizing the sources of income in the school. SD Muhamamdiyah Kleco 2 also has freedom in carrying out its activities in accordance with its authority and can be held accountable to school stakeholders.

\section{DISCUSSION}

There are 3 important findings in this study, namely: 1). the principal of the Muhammadiyah Kleco Elementary School has good entrepreneurial competence. 2). The principal of the Muhammadiyah Kleco 2 Elementary school is implementing programs that are able to maximize the potential of the school. 3). Entrepreneurship competency SDS Muhammadiyah Kleco 2 school principal is able to increase school independence.

\section{Principal Entrepreneurship Competency.}

According to (Kemendiknas, 2007) (Ministry of National Education, 2007) based on the Regulation of the Minister of National Education Number 13 of 2007 concerning the Principal / Madrasah Standards the characteristics of entrepreneurial competencies that must be possessed by a school principal are as follows. 1). Creating innovations that are useful for the development of schools / madrasas. 2). Work hard to achieve school / madrasah success as an effective learning organization. 3). Have a strong motivation to succeed in carrying out their main duties and functions as school / madrasah leaders. 4) Never give up and always look for the best solution in facing obstacles faced by schools / madrasas. 5). Having an entrepreneurial instinct in managing school / madrasah activities as a source of learning for students.

The results of the existing research, based on the above theory, are found evidence that the principal of the Muhammadiyah Kleco 2 Elementary School has good entrepreneurial competence. This can be seen from the principal's ability to read opportunities, work hard in achieving school success, create school innovations and develop entrepreneurial potential in schools

According to (Mulyasa, 2011) in the context of education, entrepreneurship refers to the condition when someone makes a decision that encourages the formation of a system of independent activities, free from the attachment of other institutions. Therefore, most drivers of change, innovation and school progress usually come from school principals who are entrepreneurial because they are leaders and education managers at the education unit level.

According to (Abbas S. d., 2004) also explained entrepreneurial competence in educational institutions containing two meanings and applications, namely: a) efforts to apply entrepreneurial values in managing educational 
institutions; b) utilize the potential possessed / can be pursued by an educational institution into economic activities so as to generate profits that can be used to advance the educational institutions concerned.

The principal of the Muhammadiyah Kleco 2 Elementary School clearly saw the opportunity to develop his school. The school principal sees the school he leads has the potential to progress, and that potential is maximized to help achieve the goals of the school and to move all elements of the school to become quality schools and become the primary choice of the community.

The principal of the Muhammadiyah Kleco 2 Elementary School is also a leader and manager and is at the forefront of innovations in schools. The headmaster always works hard in pursuing every opportunity, both in maximizing the potential within the school, as well as in opening opportunities for collaboration with other stakeholders. So that the activities in the school can really be maximized in accordance with the expectations of students and parents of students, improving services to students and parents of students is a school step towards a quality school both in terms of learning activities and extracurricular activities.

Principals are constantly innovating to pursue endless opportunities by using the most innovative strategies in producing quality graduates, graduates of SD Muhammadiyah Kleco 2 are expected to have academic and non-academic abilities that they can be proud of and useful for their future. The school principal and all school members are well aware that quality must be a major concern for the community and stakeholders as education customers to be satisfied with the production produced by the school.

\section{School Programs in Optimizing School} Potential

According to (Kusuma, 2011) a school principal with an entrepreneurial spirit are those who have courage, have a heroic spirit and develop independent ways of working. Entrepreneurship in education is continuous hard work done by the school, especially the headmaster in making his school more qualified. The concept of entrepreneurship includes an effort to read carefully the opportunities that exist, see every element of the school institution as something new or innovative, explore resources realistically and can be utilized, control risks, realize the welfare of school residents and the community

Whereas (Mutohar, 2013) explains the principal as an entrepreneur must be able to apply the principles of entrepreneurship as follows: First, acting creatively and innovatively, Second, empowering the potential of the school, Third, fostering the entrepreneurial spirit of the school community.

In the context of the realization of the principals' entrepreneurial competence, a school principal plans and implements work programs that aim to 
develop the potential of the school in order to make the better school quality school and in an effort to increase school independence. work programs undertaken by the principal include: 1). School-owned business entity (BUMS). 2). Excellent Extracurricular Program. 3\} Human Resource Development. 4). Improvement of teacher and employee welfare.

\section{Principal Entrepreneurship Competency in Increasing School Independence.}

(Wahab, 2012) said that the Independent Category Schools (SKM): schools that are able to optimize the achievement of educational goals, potential and resources owned to carry out the learning process that can develop the potential of students so as to produce quality graduates.

An independent school is a quality school, because it implements an educational process that is widely supported by all school components, the headmaster always motivates all teachers and employees that the school's quality and services must be maintained and continuously improved. With the higher quality of schools, of course, the community's trust will also be higher. With that condition also school income will be even greater and of course will have an impact on the welfare of teachers and employees.

(Mulyasa E. , 2017) Opinions in forming as effective and independent need to be considered several things, namely: (1). School planning and development. (2). Teacher and staff development. (3). Development of students. (4). Parent and community involvement. (5). Awards and incentives. (6). Order and discipline. (6). Curriculum development and learning (7). Financial management and financing. (8). Utilization of facilities and infrastructure.

The principal also utilizes his power and expertise to empower the school. This can be seen from the many innovations and school activities initiated by the school administration. This condition is justified by the statement from the teachers that the school principal really has worked hard and always empower the potential that exists in the school, both the potential of human resources and the financial potential that exists to the maximum.

The principal of the Muhammadiyah Kleco 2 Elementary School has created and implemented programs that optimize the potential of the school. Human resource development, improvement of supporting facilities for teaching and learning, quality extracurricular programs and improving the quality of learning in the classroom are efforts to improve the quality of graduates who are expected to have skills that are useful for their future. The principal has also maximized and managed sources of school income for school development. based on observations of sources of school income include: Student tuition fees that vary from Rp. 200,000 up to Rp. 250,000 . SPP funds are 
mostly used for teacher and employee salaries and student activities. For some extracurricular activities students who involve parties outside the school are asked to pay according to the needs of the relevant extracurriculars concerned.

Other financial sources are from the School Operational Assistance (BOS) funds, namely the National BOS and BOSDA. The finance from $B O S$ is managed in accordance with the specified technical guidelines. Other sources of income are donations and donors, both those that do or do not include infaq money that is coordinated by each class. This class infaq fund is also used for school operations such as for funding $H R$ for Tahfidz and $B T A Q$ activities. Sources of school income are also obtained from profits or profits from SchoolOwned Enterprises such as canteens, student cooperatives as well as sales units and textbooks. The profits obtained so far have been used for the development and purchase of supporting facilities such as the construction of the school gate, renovation of the teacher's room, purchase of a school car and the construction of a school mini market.

If we examine the explanation above, SD Muhamamdiyah Kleco 2 is already at the level of an independent school, because this school already has the initiative to meet all its needs and be able to solve its problems by optimizing the sources of income in the school. SD Muhamamdiyah Kleco 2 also has freedom in carrying out its activities in accordance with its authority and can be held accountable to school stakeholders. This can be seen from the activities carried out by the school, both training and worshop for teachers and extracurricular activities that have developed by embracing school stakeholders, the school can also be held accountable for this activity properly.

\section{CONCLUSION}

The principal of the Muhammadiyah Kleco 2 Elementary School has made creative innovations for school development. The principal has also worked hard to run the school program in order to advance the school. The principal also has the motivation to always be successful, never give up in finding solutions to every obstacle. And the principal also has a high entrepreneurial spirit in managing school activities. This basis serves as a benchmark for school entrepreneurship competencies in increasing school independence

To advance and develop the potential of the school, in order to realize an independent school, a principal who has good entrepreneurial competence is needed, a school principal who is capable and willing to take risks and innovations in every school activity. In addition, a school principal must have clear plans, goals and targets that are measurable so that they can be applied well. Principal's entrepreneurial competency also makes a principal able to read opportunities to develop his school. With these advantages, 
an effective, productive and independent school will be realized.

The principal also utilizes his power and expertise to empower the school. This can be seen from the many innovations and school activities initiated by the school administration. This condition is justified by the statement from the teachers that the school principal really has worked hard and always empower the potential that exists in the school, both the potential of human resources and the financial potential that exists to the maximum

The Principal of the Muhammadiyah Kleco 2 Elementary School has managed to explore the potential of the school and develop it into a school advantage for the betterment of the school. Designing quality activities, raising funds for the development of school buildings, and also optimizing the role of school stakeholders and the wider community are clear examples of the success of school principals in exploring and developing school potential. The development of existing potential in schools will make schools more advanced and independent

\section{References}

Abbas, S. d. (2004). Wajah dan Dinamika Pendidikan Anak Bangsa. Jakarta: Adicita Karya Nusa.

Fathurrahman Fathurrahman, A. A. (2018). The Entrepreneurial Leadership of Headmaster in Realizing
Achievement School: Case Study at Public Junior High School 1 Lamongan East Java Indonesia. Proceedings of the 3rd International Conference on Educational Management and Administration (COEMA 2018). Paris: Atlantis Press.

Kemendiknas. (2007, Maret 28). Peraturan Menteri Pendidikan Nasional No 12 Tahun 2007 Tentang Standar Kompetensi Kepala Sekolah. Diambil kembali dari http://dispendik.gresikkab.go.id/: http://dispendik.gresikkab.go.id/

Kesuma, J. P. (2011). Kewirausahaam dalam Pendidikan. Bandung: Alfabeta.

Kusuma, J. P. (2011). Kewirausahaan dalam Pendidikan. Bandung: Alfabeta.

Mulyasa. (2011). Manajemen dan Kepemimpinan Kepala Sekolah. Jakarta: Bumi Alksara.

Mulyasa, E. (2017). Manajemen Kepemimpinan Kepala Sekolah. Jakarta: Bumi Aksara.

Mutohar, P. M. (2013). Manajemen Mutu Sekolah Strategi Peningkatan Mutu dan Daya Saing Lembaga Pendidikan Islam. Jakarta: Ar Ruzz Media.

Sariyasni1, d. B. (2018). Peran Kompetensi Kewirausahaan Kepala Sekolah Dalam Peningkatan Mutu 
Pendidikan di SMAN 1 Makarti Jaya.

Prosiding Seminar Nasional

Pendidikan Program Pascasarjana Universitas PGRI Palembang $03 \mathrm{MEI}$

2019 (hal. 10). Palembang: Universitas PGRI Malang.

Wahab, R. (2012, Juni Rabu). http://staffnew.uny.ac.id. Diambil kembali dari http://staffnew.uny.ac.id/upload/1 31405893/pengabdian/strategipengembangan-sekolah-katagori- mandiri.pdf:

http://staffnew.uny.ac.id

Zaidatol Akmaliah Lope Pihie, A. S. (2018). Relationship between Entrepreneurial Leadership and School. International Journal of Academic Research in Business and Social Science, 258 - 274. 